\title{
JENIS DAN FREKUENSI KEJAHATAN DI DAERAH PARIWISATA PULAU NUSA PENIDA (PROVINSI BALI)
}

\author{
Oleh \\ I Wayan Suardana \& I Made Walesa Putra \\ Universitas Udayana \\ suardana.wayan57@yahoo.com
}

\section{ABSTRACT}

Nusa Penida is an island which located on southeast of Bali and separated by the Badung Strait. By a variety of tourist pulling magnets to come to Nusa Penida, it also gives effect to the occurrence of crime.

The purposes of the research are to develop the science of law, especially in the field of criminal law and to know and study the type and frequency of crime in Nusa Penida Tourism Area so that it can be constructed effective countermeasures formulation.

The method used in the achievement of research objectives, methods of approach Juridical Empirical, namely legal research by way of existing facts approach by way of conducting observations and research through in-depth interviews of the object research.

The result of the research shows that there are many types of criminal acts in Nusa Penida area, the most often frequency is the persecution of 24 reports, then theft of 12 reports, then another conventional crime based on data obtained from 2014 until 2017, crimes of a conventional type as stipulated in the Criminal Code and there are crimes that are classified as specific criminal acts such as narcotics abuse. Some obstacles are the existence of darknumber by reason; the omission of the community such as perceiving such acts as cock fighting, seeing guests using addictive drugs, there is also not want to take a risk by reporting an incident, even the police sometimes do not take action or ignore a suspected incident is a crime because it avoids the occurrence of threats to the apparatus itself.

Criminalization committed against such crimes as stipulated by the Criminal Code, namely Article 351, 362, 184, 338, 406, 385, 310, 187, 303, 368 and 285. However, there are also crimes threatened with the provisions of the law outside the Criminal Code : Law No. 23 of 2004 on Elimination of Domestic Violence and Law No. 22 of 2009 on Road Traffic and Transportation. There are other obstacles in relation to law enforcement in Nusa Penida crime, which is still unclear authority between Nusa Penida Police Station and Klungkung Police because of the type of crime they handled.

\section{Keywords: Type, Frequency, Crime, Nusa Penida}

\section{PENDAHULUAN}

Kejahatan adalah perbuatan manusia, yang merupakan palanggaran norma, yang dirasakan merugikan, menjengkelkan, sehingga tidak boleh dibiarkan. Kejahatan selalu menunjuk kepada perbuatan manusia dan juga batasan-batasan atau pandangan masyarakat tentang apa yang dibolehkan dan dilarang, apa yang baik dan buruk, yang semuanya itu terdapat dalam undang-undang, kebiasaan, dan adat istiadat, demikian seperti dirumuskan oleh Paul Mudigdo Moeliono. 
Kejahatan dapat terjadi dimana saja, demikian pula khususnya di Provinsi Bali yang telah merupakan salah satu pusat pariwisata dunia.

Kejahatan bukan merupakan peristiwa hereditas (bawaan sejak lahir, warisan) juga bukan merupakan warisan biologis. Tindak kejahatan bisa dilakukan siapapun baik wanita maupun pria dengan tingkat pendidkan yang berbeda. Tindak kejahatan bisa dilakukan secara sadar yaitu difikirkan, direncanakan, dan diarahkan pada maksud tertentu secara sadar benar. Kejahatan suatu konsepsi yang bersifat abstrak, dimana kejahatan tidak dapat diraba dan dilihat kecuali akibatnya saja.

Bali dikenal sampai mancanegara, tak heran bila jutaan turis datang berlibur ke Pulau Seribu Pura setiap tahunnya. Daerah pariwisata Pulau Nusa Penida adalah salah satu tempat kunjungan yang paling diminati wisatawan domestik maupun wisatawan asing.

Nusa Penida merupakan pulau terletak sebelah tenggara Bali yang dipisahkan Selat Badung. Pulau Nusa Penida merupakan pulau terbesar dari ketiga pulau (pulau Nusa Lembongan dan pulau Nusa Ceningan) dan masyarakat lokal sering menyebut dengan nama Nusa Gede. Daya tarik wisata Nusa Penida terletak pada pantai pasir putih, tempat konservasi tumbuhan langka, konservasi burung langka seperti burung Jalak Bali, serta tempat konservasi penyu hijau. Di dekat pulau ini terdapat juga pulau-pulau kecil yaitu Nusa Ceningan dan Nusa Lembongan. Perairan pulau Nusa Penida terkenal dengan kawasan selamnya di antaranya terdapat di Penida Bay, Manta Point, Batu Meling, Batu Lumbung, Batu Abah, Toyapakeh dan Malibu Point. Beberapa hal menarik yang unik dan khas dari pulau ini adalah kain tenun cepuk dan rangrang sebagai ikon, rumput laut, serta tentunya keindahan bawah laut yang masih alami.

Sekalipun merupakan salah satu tujuan pariwisata di Bali, sekitar 50\% desa di Nusa Penida tergolong miskin, Kondisi geografis dan sulitnya mendapatkan air rupanya menjadi salah satu faktor penyebab persoalan kemiskinan yang akut di Nusa Penida. Setidaknya, hal itu terlihat dari 8 dari 16 desa (50 persen) di Nusa Penida menjadi desa yang mendapat prioritas penanggulangan kemiskinan. Kedelapan desa itu, Desa Pejukutan, Tanglad, Batumadeg, Batukandik, Sekartaji, Klumpu, Bunga Mekar dan Sakti. Empat diantaranya bahkan termasuk desa rawan pangan di Nusa Penida. Dengan berpenduduk lebih dari 58 ribu jiwa, data terakhir menyebutkan angka kemiskinan di Nusa Penida mencapai 3.888 kepala keluarga (KK) atau sekitar 13 ribu jiwa.

Perairan Nusa Penida memiliki keanekaragaman sumberdaya hayati laut yang tinggi. Berdasarkan hasil survei secara cepat pada tahun 2008, di perairan Nusa Penida dijumpai 296 jenis karang keras dan 576 jenis ikan. Nusa Penida memiliki luas terumbu karang 1.419 hektar, hutan bakau seluas 230,07 hektar dan padang lamun seluas 108 hektar. Di kawasan ini juga dijumpai berbagai biota laut yang unik dan langka seperti Ikan Pari Manta, Penyu, Hiu, Dugong, Paus dan Lumba-Lumba. Bahkan di Nusa Penida terdapat salah satu ikan laut dalam yang sangat terkenal di dunia yaitu ikan Mola mola. Ikan ini kerap muncul di perairan dangkal Nusa Penida antara bulan Juli - September setiap tahunnya.

Dengan berbagai magnet penarik wisatawan untuk datang ke Nusa Penida, memberikan juga pengaruh terhadap terjadinya kejahatan di daerah tersebut. Kejahatan yang muncul antara lain, Kekerasan Dalam Rumah Tangga, kasus pencurian ikan di Kawasan Konservasi Perairan (KKP) Nusa Penida, pencurian harta benda di Fonton Bali Funtasea, Beberapa kejahatan yang dapat muncul di daerah Pulau Nusa Penida antara lain: ancaman penangkapan ikan tanpa ijin, Penangkapan ikan secara merusak, perburuan satwa laut yang dilindungi, dan pelanggaran zonasi Kawasan Konservasi Perairan (KKP) Nusa Penida. Selain terkait perikanan, kejahatan yang juga terjadi diwilayah Nusa Penida seperti: pencurian emas dan uang di Banjar Sebunibus, Desa Sakti, Kecamatan Nusa Penida, Kabupaten Klungkung, dan Kekerasan Dalam Rumah Tangga (KDRT) di Banjar Ampel, Desa Pejukutan, Kecamatan Nusa Penida. Dengan situasi dan kondisi ini diharapkan 
upaya keamanan dan ketertiban masyarakat semakin meningkat dalam mengatasi baik dari segi modus operandinya yang kian canggih maupun anatomi kejahatannya yang kian beragam. Untuk itu diharapkan aparat pemerintah dan masyarakat dapat meningkatkan kepeduliannya terhadap berbagai hal mengantisipasi gangguan-gangguan tersebut.

Dengan demikian perlu dilaksanakan penelitian yang bertujuan untuk mengetahui serta menganalisa jenis-jenis dan tingkat kejahatan di Wilayah Pariwisata Nusa Penida menganalisa pengaturan pemidanaan terhadap jenis-jenis kejahatan serta mengkaji penyebab terjadinya kejahatan tersebut sehingga dapat dilakukan segera penanggulangannya. Sehingga perlu dilakukan suatu identifikasi jenis dan frekuensi kejahatan yang terjadi di Pulau Nusa Penida, sebagai upaya meningkatkan keamanan dan kenyamanan daerah pariwisata tersebut kedepannya.

Terdapat dirumuskan dua rumusan masalah, yaitu:

1. Bagaimana jenis-jenis dan tingkat kejahatan di Wilayah Pariwisata Nusa Penida (Provinsi Bali)?

2. Bagaimana pengaturan pemidanaan terhadap jenis-jenis kejahatan di Wilayah Pariwisata Nusa Penida (Provinsi Bali)?

\section{METODE PENELITIAN}

Untuk memperoleh suatu pembahasan sesuai dengan apa yang terdapat di dalam tujuan penyusunan bahan analisis, maka dalam penulisan penelitian ini menggunakan metode pendekatan secara Yuridis Empiris, yaitu penelitian hukum dengan cara pendekatan fakta yang ada dengan jalan mengadakan pengamatan dan penelitian dilapangan kemudian dikaji dan ditelaah berdasarkan peraturan perundang-undangan yang terkait sebagai acuan untuk memecahkan masalah, dalam hal ini pendekatan tersebut digunakan untuk menganalisis secara kualitatif.

Pendekatan yuridis empiris yaitu suatu pendekatan yang dilakukan untuk menganalisis tentang sejauh mana suatu peraturan atau perundang-undangan atau hukum berlaku secara efektif dalam masyarakat, yaitu terkait jenis-jenis dan kuantitas kejahatan di daerah pariwisata Pulau Nusa Penida.

\section{TINJAUAN PUSTAKA \\ A. Tinjauan Umum Kejahatan a.Pengertian Kejahatan}

Kejahatan adalah suatu nama atau cap yang diberikan orang untuk menilai perbuatan-perbuatan tertentu, sebagai perbuatan jahat. Dengan demikian maka si pelaku disebut sebagai penjahat. Pengertian tersebut bersumber dari alam nilai, maka ia memiliki pengertian yang sangat relatif, yaitu tergantung pada manusia yang memberikan penilaian itu. Jadi apa yang disebut kejahatan oleh seseorang belum tentu diakui oleh pihak lain sebagai suatu kejahatan pula. Kalaupun misalnya semua anggota dapat menerima sesuatu itu merupakan kejahatan tapi berat ringannya perbuatan itu masih menimbulkan perbedaan pendapat.

\section{b.Penanggulangan Kejahatan}

\section{1) Upaya Penanggulangan Kejahatan dengan Sarana Non-Penal}

Menurut G.P. Hoefnagels yang dikutip oleh Barda Nawawi Arief, upaya penanggulangan kejahatan dapat ditempuh dengan:

a) Penerapan hukum pidana (criminal law application);

b) Pencegahan tanpa pidana (prevention without punishment);

c) Mempengaruhi pandangan masyarakat mengenai kejahatan dan pemidanaan lewat media massa (influencing views of society on crime and punishment/mass media).

Berdasarkan pendapat tersebut, maka upaya penganggulangan kejahatan secara garis besar dapat dibagi dua yaitu lewat jalur non-penal (bukan/di luar hukum pidana) dan jalur penal (hokum pidana). Dalam pembagian G.P. Hoefnagels diatas, upaya-upaya yang diatur dalam butir (b) dan (c) dapat dimasukkan dalam kelompok upaya non-penal. Upaya penanggulangan kejahatan lewat jalur penal lebih 
menitikberatkan pada sifat repressive (penindasan/ pemberantasan/ penumpasan) sesudah kejahatan terjadi, sedangkan jalur non-penal lebih menitikberatkan pada sifat preventive (pencegahan/penangkalan/pengendalian) sebelum kejahatan terjadi.

Upaya penanggulangan kejahatan lewat jalur non-penal lebih bersifat pencegahan untuk terjadinya kejahatan, maka sasaran utamanya adalah menangani faktor-faktor kondusif penyebab terjadinya kejahatan. Faktor-faktor kondusif itu antara lain berpusat pada masalah-masalah atau kondisi-kondisi sosial yang secara langsung atau tidak langsung dapat menimbulkan kejahatan.

Dengan demikian dilihat dari sudut politik kriminal secara makro dan global, maka upayaupaya non-penal menduduki posisi kunci dan strategis dari keseluruhan politik kriminal.

\section{2) Upaya Penanggulangan Kejahatan dengan Menggunakan Hukum Pidana (Penal)}

Menurut Gene Kassebaurn dikutip oleh Muladi dan Barda Nawawi Arief, penanggulangan kejahatan dengan menggunakan hukum pidana merupakan cara yang paling tua, setua peradaban manusia itu sendiri disebut sebagai older philosophy of crime control.

Menurut Roeslan Saleh, dikutip oleh Muladi dan Barda Nawawi Arief, tiga alasan mengenai perlunya pidana dan hukum pidana, adapun intinya sebagai berikut:

a) Perlu tidaknya hukum pidana tidak terletak pada persoalan tujuan-tujuan yang hendak dicapai, tetapi terletak pada persoalan seberapa jauh untuk mencapai tujuan itu boleh menggunakan paksaan; persoalannya bukan terletak pada hasil yang akan dicapai tetapi dalam pertimbangan antara dari hasil itu dan nilai dari batas-batas kebebasan pribadi masing-masing.

b) Ada usaha-usaha perbaikan atau perawatan yang tidak mempunyai arti sama sekali bagi terhukum; dan di samping itu harus tetap ada suatu reaksi atas pelanggaran pelanggaran norma yang telah dilakukannya itu dan tidaklah dapat dibiarkan begitu saja. c) Pengaruh pidana atau hukum pidana bukan semata-mata ditujukan kepada si penjahat, tetapi juga untuk mempengaruhi orang yang tidak jahat, yaitu warga masyarakat yang menaati norma-norma masyarakat.

\section{B.Tinjauan Umum Tindak Pidana a.Pengertian Tindak Pidana}

Istilah tindak pidana berasal dari istilah dalam hukum pidana Belanda yaitu Stafbaar feit. Walaupun istilah ini terdapat dalam WvS Belanda, dengan demikian juga WvS Hindia Belanda (KUHP) tetapi tidak ada penjelasan resmi tentang apa yang disebut dengan Stafbaar feit itu. Oleh karena itu, para ahli hukum berusaha memberikan arti dan isi dari istilah itu, Sampai kini belum ada keseragaman.

Istilah-istilah yang pernah digunakan, sebagai terjemahan dari istilah stafbaar feit sebagai berikut:

1) Tindak pidana, dapat dikatakan istilah resmi perundangan pidana kita. Hampir seluruh peraturan perundang-undangan menggunakan. Ahli hukum yang menggunakan istilah ini seperti Prof Dr Wirjono Projodikoro, S.H.( buku Tindak Pidana Tertentu di Indonesia).

2) Peristiwa Pidana, digunakan beberapa ahli hukum: Mr R Tresna (bukunya Asas-Asas Hukum Pidana), Mr Drs. H.J van Schravendijk (buku: Pelajaran tentang Hukum Pidana Indonesia), Prof.A.Zainal Abidin, SH, (buku: Hukum Pidana serta UUDS tahun 1950 (Pasal 14 ayat 1 ).

3) Delik, sebenarnya berasal bahasa latin delictum, juga digunakan menggambarkan tentang apa yang dimaksud stafbaar feit. Istilah dalam berbagai literatur; Prof Drs E Utrecht, $\mathrm{SH}$, walaupun juga beliau menggunakan 'peristiwa pidana' (Buku Hukum Pidana I). Prof A. Zainal Abidin (buku: Hukum Pidana I). Prof Moeljatno pernah menggunakan istilah ini (buku: Delik-delik Percobaan, Delik-delik Penyertaan) walaupun menurut beliau lebih tepat dengan istilah perbuatan pidana. 
4) Pelanggaran Pidana, dalam buku Pokok-pokok Hukum Pidana, ditulis oleh Mr MH Tirtaamidjaja.

5) Perbuatan yang boleh dihukum, digunakan oleh Mr Karni (buku: beliau Ringkasan tentang Hukum Pidana) juga Schravendijk (buku: Buku Pelajaran tentang Hukum Pidana Indonesia).

6) Perbuatan yang dapat dihukum, digunakan dalam UU No 12/Drt/1951 tentang Senjata Api dan Bahan Peledak (Pasal 3).

7) Perbuatan pidana, digunakan Prof. Mr. Moeljatno (buku: Asas-asas Hukum Pidana).

\section{b.Unsur-Unsur Tindak Pidana}

Unsur tindak pidana menurut Moeljatno:(1) Perbuatan; (2) Yang dilarang (oleh aturan hukum); (3)Ancaman pidana (bagi yang melanggar larangan); Perbuatan manusia saja yang boleh dilarang, oleh aturan hukum. Berdasarkan kata majemuk perbuatan pidana, maka pokok pengertian ada pada perbuatan itu, tapi tidak dipisahkan dengan orangnya. Ancaman (diancam) dengan pidana yang menggambarkan bahwa tidak mesti perbuatan itu dalam kenyataannya benarbenar dipidana. Pengertian diancam pidana merupakan pengertian umum, yang artinya pada umumnya dijatuhi pidana. Apakah in concreto orang yang melakukan perbuatan itu dijatuhi pidana ataukah tidak merupakan hal yang lain dari pengertian perbuatan pidana.

Buku II KUHP memuat rumusan tindak pidana masuk kelompok kejahatan, dan Buku III memuat pelanggaran. Ada unsur yang selalu disebutkan setiap rumusan, yaitu mengenai tingkah laku/perbuatan walaupun ada pengecualian, Pasal 351 (penganiayaan). Unsur kesalahan dan melawan hukum kadang dicantumkan, seringkali tidak dicantumkan; sama sekali tidak dicantumkan mengenai unsur kemampuan bertanggung jawab. Di samping itu, banyak mencantumkan unsurunsur lain baik sekitar/mengenai objek kejahatan maupun perbuatan secara khusus untuk rumusan tertentu. Dari rumusan-rumusan tindak pidana tertentu dalam KUHP itu, diketahui ada 11 unsur tindak pidana: (1) Unsur tingkah laku; (2) Unsur melawan hukum; (3) Unsur kesalahan; (4) Unsur akibat konstitutif; (5) Unsur keadaan yang menyertai; (6) Unsur syarat tambahan untuk dapatnya dituntut pidana; (7) Unsur syarat tambahan untuk memperberat pidana; (8) Unsur syarat tambahan untuk dapatnya dipidana; (9) Unsur objek hukum tindak pidana; (10) Unsur kualitas subjek hukum tindak pidana; dan (11) Unsur syarat tambahan untuk memperingan pidana.

Berdasarkan 11 unsur tersebut, diantaranya dua unsur yaitu kesalahan dan melawan hukum yang termasuk unsur subjetif, sedangkan selebihnya berupa unsur obyektif. Unsur melawan hukum adakalanya bersifat obyektif, misalnya melawan hukumnya perbuatan mengambil pada pencurian (Pasal 362) terletak bahwa dalam mengambil itu diluarpersetujuan atau kehendak pemilik (melawan hukum objektif). Atau Pasal 251 pada kalimat "tanpa izin pemerintah" juga pada Pasal 253, pada kalimat "menggunakan cap asli secara melawan hukum" adalah berupa melawan hukum objektif. Akan tetapi, ada juga melawan hukum subjektif misal melawan hukum dalam penipuan (oplichting, Pasal 378), pemerasan (afpersing, Pasal 368), pengancaman (afdreiging, Pasal 369) dimana disebutkan maksud untuk menguntungkan diri sendiri atau orang lain secara melawan hukum. Begitu juga unsur melawan hukum pada perbuatan memiliki dalam penggelapan (Pasal 372) yang bersifat subjektif, artinya terdapat kesadaran bahwa memiliki benda orang lain yang ada dalam kekuasaannya itu merupakan celaan masyarakat.

\section{HASIL DAN PEMBAHASAN}

A. Jenis-Jenis Dan Tingkat Kejahatan Di Wilayah Pariwisata Nusa Penida (Provinsi Bali)

Kejahatan sebagai perilaku dan perbuatan yang dapat dikenai sanksi yang ditetapkan secara resmi oleh masyarakat. Di Amerika serikat apa yang merupakan kejahatan disebutkan secara tegas dalam hukum tertulis. Khususnya undangundang negara bagian. Apa yang dimasukkan ke dalam definisi kejahatan berbeda-beda menurut yurisdiksi federal, negara bagian dan daerah. 
Para kriminolog mencurahkan banyak perhatian untuk mendefinisikan kejahatan dalam pengertian umum maupun khusus. Proses definisional ini adalah langkah maju pertama menuju tercapainya statistik kejahatan yang akurat.

Untuk menambahkan perpektif tentang kejahatan, kadang-kadang kejahatan dipandang dalam cara berbeda dari yang diberikan oleh definisi legal standar. Alternative-alternatif semacam itu dapat mendefinisikan kejahatan sehubungan dengna tipe-tipe korban (penganiayaan anak), tipe pelaku (kejahatan kerah putih), obyek kejahatan (kejahatan property), atau metode aktivitas kejahatan (kejahatan terorganisasi) .

Sebagaimana dijelaskan mengenai tindak pidana, yang disebut dengan istilah perbuatan pidana oleh Moeljatno. Perbuatan pidana diartikan sebagai "perbuatan yang dilarang dalam undangundang dan diancam dengan pidana barangsiapa melanggar larangan itu".

Jenis-jenis kejahatan yang terjadi di wilayah Nusa Penida berdasarkan data yang diperoleh di Kepolisian Sektor Nusa Penida dianalisa dalam pengaturan perundang-undangan hukum pidana nasional baik di dalam Kitab Undang-Undang Hukum Pidana (KUHP) maupun di luar KUHP maka dapat digolongkan sebagai berikut:

1) Penganiayaan, sebagaimana disebutkan pada laporan kasus no: LP/01/I/2014/ Bali/Res KLK (mencekik), LP/02/I/2014/ Bali/Res KLK/ Sek.NP (memukul), LP/04/II/2014/ Bali/Res KLK/Sek.NP (penamparan), LP/05/II/2014/ Bali/Res KLK/Sek.NP (pemukulan), LP/08/ III/2014/Bali/Res KLK/Sek.NP (pemukulan), LP/10/III/2014/ Bali/Res KLK/Sek.NP (pemukulan dan penendangan), LP/11/III/ 2014/ Bali/Res KLK/Sek.NP (pemukulan dengan sapu ijuk), LP/14/VIII/ 2014/ Bali/Res KLK/Sek.NP (pencekikan), LP/15/VIII/ 2014/ Bali/Res KLK/Sek.NP (penganiayaan di sekolah), LP/17/X/2014/Bali/Res KLK/ Sek.NP (penganiayaan), LP/19/X/2014/ Bali/ Res KLK/Sek.NP (penganiayaan), LP/22/XII/ 2014/Bali/Res KLK/Sek.NP (pembantingan), LP/01/I/ 2015/ Bali/Res KLK/Sek.NP (pembacokan), LP/02///2015/ Bali/Res KLK/ Sek.NP (pencakaran), LP/09/III/ 2015/ Bali/
Res KLK/Sek.NP (penganiayaan), LP/10/III/ 2015/Bali/Res KLK/Sek.NP (penganiayaan), LP/14/04/ 2015/ Bali/Res KLK/Sek.NP (pemukulan), LP/21/VII/ 2015/Bali/Res KLK/ Sek.NP (pemukulan dengan kayu), LP/22/VII/ 2015/Bali/Res KLK/Sek.NP (penganiayaan), LP/31/XI/ 2015/ Bali/Res KLK/Sek.KLK (pemukulan), LP/08/IV/2016/Bali/Res KLK/ Sek.NP (penganiayaan),LP/08/IV/2016/ Bali/ Res KLK/Sek.NP (penganiayaan), LP/08/IV/ 2017/Bali/Res KLK/Sek.NP (penganiayaan), LP /09/IV/ 2017/ Bali/Res KLK/Sek.NP (penganiayaan).

2) Pencurian, laporan kasus no: LP/03/II/2014/ Bali/Res KLK/Sek.NP (mencuri perhiasan), LP/05/II/ 2015/ Bali/Res KLK/Sek.NP (pencurian di warung), LP/06/II/ 2015/ Bali/ Res KLK/Sek.NP(pencurian di sekolah), LP/ 07/II/ 2015/Bali/Res KLK/Sek.NP (pencurian perhiasan), LP/15/V/ 2015/ Bali/Res KLK/ Sek.NP (pencurian bola lampu), LP/17/V/ 2015/ Bali/Res KLK/Sek.NP (pencurian batang pohon kelapa), LP /02/I/ 2016/ Bali/ Res KLK/Sek.NP (pencurian balok kayu), LP/ 06/III/ 2016/ Bali/Res KLK/Sek.NP (pencurian dana punia), LP/13/V/2016/ Bali/ Res KLK/Sek.NP (pencurian uang di bengkel), LP /15/VII/ 2016/ Bali/Res KLK/Sek.NP (pencurian uang di ATM), LP/17/VIII/ 2016/ Bali/Res KLK/Sek.NP (pencurian uang), LP / 30/IX/ 2016/ Bali/Res KLK/Sek.NP (pencurian uang), LP/32/X/2016/Bali/Res KLK/Sek.NP (pencurian), LP /31/XI/ 2016/ Bali/Res KLK/Sek.NP (pencurian perhiasan), LP-B /02/III/ 2017/ Bali/Res KLK/Sek.NP (pencurian uang di sadle motor), LP-B /03/III/ 2017/ Bali/Res KLK/Sek.NP (pencurian laptop).

3) Perkelahian, laporan kasus no: LP/13/VIII/ 2014/Bali/Res KLK/Sek.NP (perkelahian), LP /09/IV/ 2016/ Bali/Res KLK/Sek.NP (perkelahian).

4) Percobaan pembunuhan, laporan kasus no: LP/ 01/I/ 2015/ Bali/Res KLK/Sek.NP (pembacokan). 
5) Pengerusakan, laporan kasus no: LP/05/III/ 2015/Bali/Res KLK/Sek.NP (pengrusakan di atas tanah sengketa), LP-B/01/I/ 2016/ Bali/ Res KLK/Sek.NP (pengrusakan rumah).

6) Penyerobotan lahan, laporan kasus no: LP/12/ IV/2015/Bali/Res KLK/Sek.NP (penebangan pohon dilanjutkan pengukuran lahan di lahan korban).

7) Penghinaan, laporan kasus no: LP/01/I/2014/ Bali/Res KLK (menghina), LP/03///2015/Bali/ Res KLK/Sek.NP (penghinaan), LP/13/IV/ 2015/Bali/Res KLK/Sek.NP (mencaci maki).

8) Pembakaran, laporan kasus no: LP/18/V/ 2015/ Bali/Res KLK/Sek.NP.

9) Kekerasan Dalam Rumah Tangga (KDRT), laporan kasus no: LP-B/D8/VI/2015/Bali/Res KLK/Sek.NP/ Polsubsektor Lbg.

10) Perjudian, laporan kasus no: LP/04/I/ 2015/ Bali/Res KLK/Sek.NP (jual judi togel), LPA/29/X/ 2015/ Bali/Res KLK/Sek.NP (judi dadu), LP-A /37/XII/ 2016/ Bali/Res KLK/ Sek.NP (judi togel).

11) Pengancaman, laporan kasus no: LP/05/III/ 2016/ Bali/Res KLK/Sek.NP (ancaman lewat SMS).

12) Perkosaan, laporan kasus no: LP/01/II/ 2017/ Bali/Res KLK/Sek.NP (perkosaan oleh orang asing).

13) Kecelakaan, laporan kasus no: LP-B /05/III/ 2017/Bali/Res KLK/Sek.NP (kecelakaan).

14) Pengakibatkan perasaan tidak enak, laporan kasus no: LP/18/X/ 2014/ Bali/Res KLK/ Sek.NP.

Berdasarkan pada laporan yang diterima Polsek Nusa Penida dari tahun 2014 hingga 2017, maka laporan dugaan tindak pidana yang paling banyak terjadi adalah penganiayaan. Presentase kejahatan yang dilaporkan di Nusa Penida yaitu sebanyak 24 laporan kasus penganiayaan atau sekitar 30\% dari 80 laporan, kemudian disusul oleh kejahatan pencurian sebanyak 12 laporan kasus atau sekitar $15 \%$ dari 80 laporan, sedangkan sisanya sekitar $65 \%$ terbagi jumlahnya hampir rata terhadap 12 jenis kejahatan yaitu: Perkelahian, Percobaan pembunuhan. Pengerusakan,
Penyerobotan lahan, Penghinaan, Pembakaran, Kekerasan Dalam Rumah Tangga, Perjudian, Pengancaman, Perkosaan, Kecelakaan, dan Pengakibatkan perasaan tidak enak. Ada juga kasus pembuatan tempat usaha terapung secara melawan hukum yang dapat merusak alam yaitu terumbu karang dibawahnya dan kasus penggunaan compressor secara melawan hukum.

Berdasarkan data yang diperoleh di Polsek Nusa Penida merupakan suatu statistic criminal, dimana pengumpulan dan pengolahan data statistik yang merupakan hasil pencatatan oleh kepolisian yang tentunya sangat dipengaruhi oleh kemauan masyarakat atau korban melapor yang juga mempertimbangkan hal yaitu jenis kejahatan, besar-kecilnya kerugian, persepsi terhadap kemampuan penegak hukum ataupun hubungan korban dengan pelaku. Sebagaimana kondisi di Nusa Penida diperoleh data bahwa terdapat beberapa hal yang mengakibatkan tidak terlaporkannya seluruh tindak pidana yang terjadi didaerah tersebut sebagaimana yang dikenal dengan istilah dark number.

Sekalipun beberapa kasus dugaan tindak pidana telah ditangani oleh kepolisian setempat namun tingkat dark numbers yaitu kasus yang terselubung masih cukup tinggi dengan beberapa alasan antara lain: pembiaran masyarakat seperti menganggap perbuatan tersebut telah biasa terjadi seperti adu ayam, atau melihat tamu yang menggunakan obat adiktif tertentu, ada juga masyarakat yang tidak ingin mengambil resiko melaporkan suatu kejadian, bahkan polisi terkadang tidak mengambil tindakan atau mengabaikan suatu kejadian yang diduga adalah tindak pidana karena menghindari terjadinya ancaman terhadap aparat sendiri.

Upaya yang dilakukan Polsek Nusa Penida untuk mengantisipasi meningkatnya tingkat kriminalitas dan kenakalan remaja yaitu melaksanakan giat patroli dialogis yaitu terhadap remaja-remaja yang "ngumpul-ngumpul" di Pelabuhan tradisional Buyuk dan menyampaikan beberapa pesan kamtibnas untuk tidak melakukan hal-hal yang dapat merugikan masyarakat dan meningkatkan belajar mengisi masa depan. 
Sementara itu di Wilayah Nusa Lembongan dianggap wilayah kepulauan di Kabupaten Klungkung yang rentan dengan peradaran narkoba. Berdasarkan data Polres Klungkung penangkapan narkoba meningkat di tahun 2015 ada 7 kasus, meningkat di tahun 2016 menjadi 16 kasus. Dari 16 kasus, 9 tersangka sebagai pamakai, dan 7 tersangka adalah pengedar. Sementara itu dari Januari hingga April 2017 personel Satuan Narkoba Polres Klungkung berhasil mengungkap 3 kasus penyalahgunaan narkoba dengan total 3 tersangka. Polres Klungkung telah sepakat dengan Majelis Madya Desa Pakraman, Majelis Alit Desa Pakraman, BNNK Klungkung agar penyalahgunaan narkoba dapat dituangkan dalam pararem di seluruh desa pakraman di Klungkung. Pararem untuuk memerangi narkoba di desa pekraman dapat dituangkan dalam pararem ngele atau bersifat khusus di 119 desa pakraman yang tersebar di empat kecamatan di Klungkung.

Perjudian menjadi darknumber karena banyak bersembunyi dibalik acara adat. Sedangkan kejahatan narkoba juga dirasakan sulit mendeteksinya. Faktor yang mengakibatkan timbulnya darknumber karena bersembunyi dibalik kedok upacara selain itu faktor petugas kepolisian yang sedikit, selain itu pengaruh fasilitas yang kurang memadai untuk penanggulan pencurian ikan (kapal kurang kuantitas maupun kurang canggih) juga faktor pembiaran terjadi karena menghindari ancaman terhadap aparat sendiri.

Data dari KBO Reskrim Polres Klungkung: Sabung ayam masih terjadi di daerah Nusa Penida namun harus terkait dengan upacara adat, diluar acara adat tidak diperbolehkan. Untuk dapat mengadakan sambung ayam keperluan upacara adat atau disebut tabuh rah maka harus mengajukan surat pemberitahuan kepada kepolisian. Untuk kejahatan yang sifatnya transnasional belum ditemukan seperti illegal fishing selama ini sifatnya hanya dilakukan oleh penduduk lokal nusa ataupun daerah sekitar (seperti yang beberapa kasus terjadi pelaku dari lombok). Sebab kejahatan di Nusa Penida lebih banyak diakibatkan oleh permasalahan ekonomi yang utama.

Sementara itu berdasarkan data Badan Pusat Statistik Tahun 2016 bahwa data tindak pidana menurut Kepolisian Sektor di Nusa Penida yaitu:

\begin{tabular}{|l|l|l|l|l|}
\hline No & \multicolumn{1}{|c|}{ Keterangan } & Tahun 2013 & Tahun 2014 & Tahun 2015 \\
\hline 1 & $\begin{array}{l}\text { Jumlah Tindak } \\
\text { Pidana }\end{array}$ & 10 & 14 & 12 \\
\hline 2 & $\begin{array}{l}\text { Persentase } \\
\text { penyelesaian tindak } \\
\text { pidana }\end{array}$ & $60 \%$ & $100 \%$ & $50 \%$ \\
\hline
\end{tabular}

Pemaparan data yang diberikan BPS di Tahun 2016 menunjukkan bahwa ada beberapa tindak pidana yang terjadi sejak tahun 2013 sampai dengan tahun 2015, dengan membandingkan dalam tiga tahun tersebut maka tindak pidana yang paling banyak terjadi adalah di tahun 2014 yaitu dengan 14 kasus kemudian di tahun 2015 dengan 12 kasus serta di tahun 2013 dengan sejumlah 10 kasus tindak pidana. Berdasarkan jumlah tersebut hanya di tahun 2014 dimana penyelesaian tindak pidana secara maksimal yaitu $100 \%$ sementara itu di tahun 2013 dan tahun 2015 masing-masing berturut sebesar $60 \%$ dan $50 \%$ penyelesaian berdasarkan frekuensi yang ada.

\section{B. Analisa Pemidanaan Terhadap Jenis-Jenis Kejahatan Di Wilayah Pariwisata Nusa Penida (Provinsi Bali)}

Beberapa pakar menjelaskan yang dimaksud pemidanaan (Straftoemeting-Bld, Sentencing-Inggris) atau Penjatuhan Pidana adalah:

- Sudarto, Pemidanaan sinonim dengan Penghukuman, yaitu berasal dari kata hukum, sehingga diartikan menetapkan hukum atau memutuskan tentang hukumnya (berechten).

- Andi Hamzah, Pemidanaan disebut juga penjatuhan pidana atau pemberian pidana atau penghukuman. Pemberian pidana ini mempunyai dua arti yaitu:

1) Dalam arti umum, menyangkut pembentuk undang-undang ialah yang menetapkan 
stelsel sanksi hukum pidana (pemberian pidana in abstracto).

2) Dalam arti konkrit, ialah yang menyangkut berbagai badan atau jawatan yang kesemuanya mendukung dan melaksanakan stelsel sanksi hukum pidana itu.

Di Indonesia, hukum positif belum pernah merumuskan tujuan pemidanaan. Selama ini wacana tentang tujuan pemidanaan tersebut masih dalam tataran yang bersifat teoritis. Tujuan pemidanaan menurut Wirjono Prodjodikoro, yaitu: 1) Untuk menakut-nakuti orang jangan sampai melakukan kejahatan baik secara menakut-nakuti orang banyak (generals preventif) maupun menakut-nakuti orang tertentu yang sudah melakukan kejahatan agar dikemudian hari tidak melakukan kejahatan lagi (speciale preventif), atau

2) Untuk mendidik atau memperbaiki orang-orang yang melakukan kejahatan agar menjadi orangorang yang baik tabiatnya sehingga bermanfaat bagi masyarakat.

Pada dasarnya terdapat tiga pokok pemikiran tentang tujuan yang ingin dicapai dengan suatu pemidanaan, yaitu:

1) Memperbaiki pribadi dari penjahatnya itu sendiri;

2) Membuat orang menjadi jera melakukan kejahatan-kejahatan;

3) Membuat penjahat-penjahat tertentu menjadi tidak mampu untuk melakukan kejahatankejahatan yang lain, yakni penjahat-penjahat yang dengan cara-cara lain sudah tidak dapat diperbaiki kembali.

Melihat pada tujuan dari pemidanaan yang ingin dicapai diantaranya diharapkan ada efek jera pelaku agar tidak mengulangi perbuatannya selain juga untuk memperbaiki pelaku menjadi lebih baik berdasarkan sanksi pidana yang telah dijatuhkan. Berikut ancaman sanksi pidana yang diatur di dalam maupun di luar KUHP terhadap kejahatankejahatan di Nusa Penida dilakukan suatu analisa: 1) Ancaman sanksi pidana penganiayaan, Pasal 351 KUHP
Rumusan delik ini tidak terdiri atas bagian inti hanya disebut "penganiayaan" (mishandeling) karena sangat sulit membuat rumusan atau definisi mengenai penganiayaan karena ribuan cara orang untuk menganiaya. Di ayat (4) diberi pengertian dengan apa yang dimaksud dengan penganiayaan, yaitu "dengan sengaja merusak kesehatan orang”. Kalau demikian penganiayaan tidak mesti melukai orang. Membuat orang tidak bisa bicara, membuat orang lumpuh termasuk pengertian ini. Penganiayaan bisa berupa pemukulan, penjebakan, pengirisan, membiarkan anak kelaparan, memberikan luka dan cacat.

2) Ancaman sanksi pidana pencurian, Pasal 362 KUHP

Bagian inti delik (delicts bestanddelen) yang menjadi definisi semua jenis delik pencurian adalah: (1) Mengambil suatu barang (enig goed); (2) Yang seluruhnya atau sebagian kepunyaan orang lain; Dengan maksud untuk memiliki secara; Melawan hukum.

3)Ancaman sanksi pidana perkelahian, Pasal 184 KUHP

Menurut Pasal 184 KUHP pada ayat (1) menjelaskan perang tanding ini dikenai hukuman maksimum sembilan bulan penjara terhadap pihak yang tidak melukai lawannya. Menurut ayat (2) hukuman itu menjadi satu tahun empat bulan bagi pihak yang mengakibatkan luka biasa pada lawannya, dan menurut ayat (3) menjadi empat tahun penjara apabila mengakibatkan luka berat, dan akhirnya menurut ayat (4) menjadi tujuh tahun penjara apabila akibat ini adalah matinya seseorang. Apabila duel diadakan "hidup atau mati" (op leven en dood) yang berarti duel tidak dihentikan sebelum salah satu atau keduanya mati, maka hukuman bagi yang masih hidup dijadikan maksimum dua belas tahun penjara. Pada ayat (5) menyatakan percobaan untuk perang tanding ini tidak dikenai hukuman.

4) Ancaman sanksi pidana percobaan pembunuhan, Pasal 53 jo 338 KUHP

Bagian inti delik sebagai berikut: 
- Dengan sengaja; Kesengajaan disini ditujukan kepada hilangnya nyawa orang lain, inilah yang membedakan dengan penganiayaan yang mengakibatkan kematian, karena dalam hal penganiayaan, tidak ada maksud atau kesengajaan untuk menghilangkan nyawa orang. Matinya orang itu hanya akibat dari penganiayaan.

- Merampas nyawa seorang lain; hilangnya nyawa sebagai tujuan kesengajaan harus terjadi. Sebenarnya disini terjadi unsur materiil penganiayaan dalam arti merusak kesehatan orang, delik terjadi jika nyawa hilang. Di sini terjadi kausalitas antara perbuatan kesengajaan dan kematian.

5) Ancaman sanksi pidana pengerusakan, Pasal 406 KUHP

Bagian inti delik: (1) Sengaja; (2) dan melawan hukum; (3) Menghancurkan, merusakkan, membikin tidak dapat dipakai atau menghilangkan suatu barang; (4) Yang seluruhnya atau sebagian milik orang lain. Ayat (2) pidana yang sama tetapi objeknya adalah hewan, dibunuh, dirusakkan, membikin tidak dapat dipakai atau menghilangkannya. Agak sulit untuk merumuskan "menghancurkan atau merusak" hewan, sehingga menjadi "membunuh, merusakkan, membikin tidak dapat digunakan atau menghilangkan hewan. Delik ini adalah delik sengaja dan melawan hukum.

6) Ancaman sanksi pidana penyerobotan lahan, Pasal 385 KUHP

Delik pasal ini biasa disebut stellionnaat, yang khas Indonesia yang menyangkut tanah dengan hak pakai pribumi.

7) Ancaman sanksi pidana penghinaan, Pasal 310 KUHP

Delik ini delik sengaja, artinya pelaku memang berkehendak mencemarkan namabaik orang itu. Jika yang dicemarkan nama baiknya itu memang melakukan delik yang dituduhkan, tidak dapat dipidana pelaku penghinaan. Begitu pula jika dia berbuat untuk kepentingan umum (algemeen belang; public interest) tidak dipidana. Hal ini merupakan dasar pembenar secara khusus dalam undang-undang. Untuk kepentingan umum jika memang hal itu menjadi pekerjaannya. Hakim, wajib memeriksa apakah memang dia bertindak untuk kepentingan atau karena terpaksa untuk membela diri. Jika dia diberikan kesempatan untuk membuktikan tuduhannya dan dia tidak dapat, dan tuduhan bertentangan dengan yang dia ketahui maka akan menjadi delik fitnah (Pasal 311 KUHP) yang dipidana jauh lebih berat, yaitu maksimum empat tahun penjara.

8) Ancaman sanksi pidana pembakaran, Pasal 187 KUHP

"Membakar" kini tidak berarti sembarang membuat api dari sesuatu tetapi menjadikan api dari barang-barang yang tidak ditujukan untuk dibakar. Maka, tidak merupakan tindak pidana dari pasal ini apabila orang membuat api untuk memasak nasi atau makanan lain, atau apabila Pramuka membuat api unggun. Dalam hal membakar sampah dipinggir jalan raya, meskipun dianjurkan oleh pemerintah kota, hal ini harus dilakukan tidak terlalu dekat dengan suatu rumah tinggal dan disekitarnya harus tidak ada tersimpan barang-barang yang mudah terbakar seperti BBM. Apabila syarat-syarat itu tidak dipebuhi dan kemudian ternyata barang-barang lain di sekitarnya ikut terbakar, maka tentu orang yang membakar sampah tadi telah bersalah melakukan tindak pidana dari pasal 188, yaitu menyebabkan kebakaran secara culpa.

9) Ancaman sanksi pidana KDRT,: ancaman UU 23 tahun 2004 tentang Penghapusan Kekerasan Dalam Rumah Tangga

10) Ancaman sanksi pidana perjudian, Pasal 303 KUHP

11) Ancaman sanksi pidana pengancaman, Pasal 369 KUHP

Bagian inti delik ini sama dengan pemerasan (Pasal 368 KUHP), ditambah satu bagian inti lagi, yaitu "dengan ancaman akan membuka rahasia". Jadi pelaksanaannya itu berupa akan membuka rahasia korban jika tidak diberi sesuatu dan seterusnya itu. Jika dilakukan 
pengaduan, maka tentu rahasia pengadu justru terbongkar pada umum.

12) Ancaman sanksi pidana perkosaan, Pasal 285 KUHP

Bagian inti delik adalah: (1) Dengan kekerasan atau ancaman kekerasan; (2) Memaksa; (3) Dengan perempuan yang bukan isterinya; (4) Terjadi persetubuhan.

13) Ancaman sanksi pidana menabrak orang, Pasal 310 UU No 22 Tahun 2009 tentang Lalu Lintas dan Angkutan Jalan.

14) Ancaman sanksi pidana pengakibatkan perasaan tidak enak, Pasal 335 KUHP namun dinyatakan tidak berlaku oleh Putusan MK.

Beberapa laporan lainnya tidak tergolong sebagai kejahatan seperti peristiwa kebakaran (kios, rumah dan mobil), kehilangan barang, peristiwa tanah longsor, peristiwa jebolnya jembatan, peristiwa terseret arus dan tenggelam, atau pelaku bunuh diri.

Pemidanaan yang dilakukan terhadap tindak pidana tersebut dikarenakan merupakan kejahatan konvensional sehingga sebagaimana yang diatur dalam KUHP yaitu antara lain Pasal 351, 362, $184,338,406,385,310,187,303,368$, dan 285 . Namun ada juga tindak pidana yang diancam dengan ketentuan undang-undang diluar KUHP yaitu antara lain dengan UU 23 tahun 2004 tentang Penghapusan Kekerasan Dalam Rumah Tangga serta UU No 22 Tahun 2009 tentang Lalu Lintas dan Angkutan Jalan.

\section{KESIMPULAN DAN SARAN}

\section{A. Kesimpulan}

1) Frekuensi jenis tindak pidana di daerah Nusa Penida yang paling sering terjadi adalah penganiayaan sejumlah 24 laporan, kemudian pencurian sejumlah 12 laporan, sebagai jumlah kedua terbanyak. Sementara itu data yang diperoleh mulai tahun 2014 sampai dengan 2017 ini, jenis kejahatan terjadi adalah kejahatan yang sifatnya konvensional sebagaimana diatur dalam KUHP serta ada kejahatan yang tergolong tindak pidana khusus seperti penyalahgunaan narkotika. Dengan demikian suatu identifikasi jenis dan frekuensi kejahatan yang terjadi di Pulau Nusa Penida, sebagai upaya meningkatkan keamanan dan kenyamanan daerah pariwisata tersebut kedepannya. Beberapa kendala adanya darknumber yaitu data kejahatan yang tidak terlaporkan antara lain; pembiaran masyarakat seperti menganggap perbuatan tersebut telah biasa terjadi seperti adu ayam, atau melihat tamu yang menggunakan obat adiktif tertentu, ada juga masyarakat yang tidak ingin mengambil resiko melaporkan suatu kejadian, bahkan polisi terkadang tidak mengambil tindakan atau mengabaikan suatu kejadian yang diduga adalah tindak pidana karena menghindari terjadinya ancaman terhadap aparat sendiri.

2) Pemidanaan yang dilakukan terhadap tindak pidana tersebut dikarenakan merupakan kejahatan konvensional sehingga sebagaimana yang diatur dalam KUHP yaitu antara lain Pasal 351, 362, 184, 338, 406, 385, 310, 187, 303, 368 , dan 285. Namun ada juga tindak pidana yang diancam dengan ketentuan undangundang diluar KUHP yaitu antara lain dengan UU 23 tahun 2004 tentang Penghapusan Kekerasan Dalam Rumah Tangga serta UU No 22 Tahun 2009 tentang Lalu Lintas dan Angkutan Jalan. Ada kendala sehubungan dengan penegakkan hukum terhadap tindak pidana di Nusa Penida, yaitu masih belum kejelasan kewenangan antara Polsek Nusa Penida dan Polres Klungkung sehubungan jenis tindak pidana yang mereka tangani.

\section{B. Saran}

1) Perlu dilakukan pendekatan oleh aparat penegak hukum dalam hal ini adalah kepolisian bahwa pentingnya melapor tindak pidana yang terjadi sebagai upaya mendapatkan data yang sebenarnya jenis dan frekuensi tindak pidana sehingga dapat dilakukan penanggulangan yang efektif.

2) Statistik jumlah kejahatan di Nusa Penida dimana terjadi darknumber akan mempengaruhi terhadap analisa pemidanaannya, sehingga dimungkinkan ada 
tindak pidana yang tidak terungkap yang justru seharusnya pelaku dikenakan pidana. Ini akan mempengaruhi efek jera pelaku ataupun masyarakat setempat sehubungan teori tujuan pemidanaan. Dilain pihak perlu koordinasi yang lebih baik antara kepolisian sektor Nusa Penida dan Kepolisian Resor Klungkung dalam pembagian tugas tindak pidana yang mana yang menjadi tugas dan kewajiban masing-masing institusi untuk menanganinya.

\section{DAFTAR PUSTAKA}

\section{Buku}

Arief, Barda Nawawi, 1996, Upaya Non Penal Dalam Kebijakan Penanggulangan Kejahatan,Semarang.

Chazawi, Adami, 2014, Pelajaran Hukum Pidana Bagian I, PT RajaGrafindo Persada, Jakarta.

Hagan, Frank E., 2013, Pengantar Kriminologi Teori, Metode, dan Perilaku Kriminal, Edisi 7, Kencana Prenada Group, Jakarta. Hamzah, Jur Andi, 2009, Delik-delik tertentu di dalam KUHP, Sinar Grafika, Jakarta

Kertanegara, Satochid, Tanpa Tahun, Hukum Pidana Bagian I, Balai Lektur Mahasiswa. Kuntjaraningrat, 1999, Kebudayaan, Metalitet \& Pembangunan, Gramedia, Jakarta.

Kusumah, Mulyana W., 1984, Kriminologi dan Masalah Kejahatan (Suatu Pengantar Ringkas), Armco, Bandung.

Lamintang, P.A.F, 1988, Hukum Penitensier Indonesia, Armico, Bandung.
Muladi dan Barda Nawawi Arief, 1998, Teoriteori dan Kebijakan Pidana, Bandung, Alumni.

Prodjodikoro, Wirjono, 2003, Asas-asas Hukum Pidana Di Indonesia, Repika Aditama, Bandung. , 1981, Hukum Acara Pidana di Indonesia, Sumur Bandung, Bandung , 2008, Tindak-

Tindak Pidana Tertentu di Indonesia, Refika Aditama, Bandung

Santoso, Topo dan Eva Zulfa, 2001, Kriminologi, Raja Grafindo Persada, Jakarta.

Setiady, Tolib, 2010, Pokok-Pokok Hukum Penitensier Indonesia, Alfabeta, Bandung

Soemitro, Rony Hanitijo, 1998, Metode Penelitian Hukum dan Jurimetri, Ghalia Indonesia, Jakarta.

Soetrisno Hadi, 1985, Metodologi Reseacrh Jilid II, Yayasan Penerbit Fakultas Psikologi UGM,Yogyakarta.

\section{Website}

https://id.wikipedia.org/wiki/Nusa_Penida.

http://citizenbali.com, KKP Nusa Penida, Rawan Incaran Pencuri Ikan, Santana ja Dewa, 05 September 2016

$\mathrm{http}$ ://balicaringcommunity.org/50-persen-desa-dinusa-penida-tergolong-miskin.html

http://metrobali.com/2016/11/05/polisi-ungkapkasus-pencurian-di-nusa-penida

http://klungkung.polda-bali.com/berita-polseknusa-penida-ungkap-kasus-pencurianemas.html

Pemerintah Kabupaten Klungkung, 2012. 